\title{
PODERES INVISÍVEIS VERSUS PODERES VISÍVEIS NO LEVIATÃ DE THOMAS HOBBES ${ }^{1}$
}

\author{
Pedro Hermílio Villas Bôas Castelo Branco
}

\begin{abstract}
RESUMO
O conceito de secularização adotado pelas teorias do Estado moderno permitiu institucionalizar um Estado laico que alterou a concepção de legitimidade, solapando qualquer possibilidade de reivindicação do poder divino pelos governantes. Hoje, porém, depois do 11 de setembro de 2001, acentuou-se a necessidade de repensar o conceito de secularização, precisamente, à luz do papel que a religião desempenha na política interna e externa dos estados. Este artigo sugere que o conceito de secularização nem sempre foi pensado como separação entre o poder espiritual e o poder temporal. A investigação do Leviatã de Thomas Hobbes, obra apontada por muitos como precursora da teoria do Estado moderno, indica outro sentido para a compreensão do conceito de seculariação.
\end{abstract}

PALAVRAS-CHAVE: conceito de secularização; Estado e Igreja; poderes visíveis e poderes invisíveis; Direito e moral; Leviatã; Positivismo Jurídico.

\section{INTRODUÇÃO}

A secularização ${ }^{2}$ é um conceito imprescindível para descortinar as teorias do Estado Moderno. Revela em si uma estrutura dualística entre o espiritual (poder invisível) e o temporal (poder visível), entre o sagrado e o profano, entre o eterno

1 Trabalho apresentado no I ${ }^{\mathrm{o}}$ Simpósio Universidade de São Paulo-Instituto Universitário de Pesquisas do Rio de Janeiro de Pós-gradução em Teoria Política, realizado de 24 a 26 de setembro de 2003 em São Paulo.

2 Em importante trabalho, Flávio Pierucci chama atenção para "necessidade inadiável de reabrirmos hoje no Brasil, entre sociólogos da religião, a discussão conceitual do problema da secularização" (PIERUCCI, 1998, p. 43). Embora o autor defenda a discussão do referido conceito no âmbito da sociologia da religião, seu ensaio consiste em uma abordagem política e jurídica do conceito. Aliás, neste trabalho, como se verá adiante, sustenta-se a necessidade de empreender-se uma investigação da categoria para uma devida compreensão de alguns pressupostos políticos do Estado moderno. Recentemente Pierucci redigiu o livro Desencantamento do mundo, no qual busca reconstruir o conceito de "desencantamento" na obra de Max Weber. Aduz os diversos usos que o autor teria feito do conceito, chegando à conclusão que desde o início de sua produção intelectual Weber teria já teria utilizado o termo desencantamento como base de explicação do surgimento da modernidade ocidental (PIERUCCI, 2003, p. 216). e o secular, entre a civitas dei e civitas hominis. Embora se afirme que tal categoria do tempo (a secularização) teria surgido, primeiramente, no âmbito jurídico-político, ela contém uma profusão de significados que se estende a diversas áreas do saber, como a Política, a Literatura, a História, a Filosofia, a Sociologia, a Teologia e o Direito. Se, por um lado, a investigação do conceito de secularização desvela uma amplitude semântica em vários campos do saber, por outro, observa-se que vai sendo, paulatinamente, elevada à condição de categoria genealógica capaz de sintetizar o desenvolvimento histórico da moderna sociedade ocidental desde suas raízes judaico-cristãs (MARRAMAO, 1997, p. 15).

A despeito de declarar-se que a mencionada categoria estaria, potencialmente, apta a reconstruir a autocompreensão das teorias do Estado Moderno, seria uma veleidade não se apontar as aporias, antinomias e os paradoxos que encerra o conceito de secularização, cuja raiz está enredada em um jogo de disputas entre o altar e o trono, entre auctoritas e potestas, entre ética e política, entre Direito e Moral, enfim, entre a Igreja e o Estado. Ora, poder-se-ia indagar de que modo uma categoria, coextensiva a tantas áreas do conhecimento, pode consistir em um instrumento capaz de reconstruir a forma por que se estruturam jurídica e politicamente as relações sociais na 
Europa a partir do momento em que se acentuou o processo de solapamento da ordem feudal, fundada, sobretudo, nos costumes provenientes de leis divinas e nos privilégios derivados dos sistemas de suserania e vassalagem.

Entre outros sentidos que vai assumindo o conceito de secularização, como o da passagem de um padre regular à condição de padre secular e o da expropriação de bens eclesiásticos em favor de domínios temporais, observa-se que a categoria ampliou-se a ponto de assumir o significado de uma Filosofia da História. Boa parte das investigações sobre o referido conceito têm-se dirigido a esse sentido. Koselleck, por exemplo, relata que "um dos principais alvos da crítica à religião cristã trouxe em suas múltiplas divisões a herança de uma história sagrada que foi retomada, das mais diversas formas, por uma visão de mundo voltada para o futuro. É conhecido o processo de secularização, no qual a escatologia foi transportada para uma história progressista. Nossa investigação mostrará que os elementos do juízo divino e do juízo final também passaram a ser aplicados consciente e deliberadamente à própria história" (KOSELLECK, 1999, p. 15).

Este artigo tem como objetivo examinar o significado do conceito de secularização na obra mais conhecida e a fortiori mais enigmática de Thomas Hobbes (1588-1679), isto é, no "maior texto secularizante do Ocidente, o Leviatã" (ROMANO, 1997), publicado em 1651. Pretendo examinar em que medida o conceito de secularização realmente corresponde ao desgaste de valores de fé e de autoridade e, mais precisamente, à progressiva erosão dos fundamentos teológico-metafísicos no campo da política, cuja conseqüência consistiria na abertura à contingência, à imprevisibilidade e à incerteza, justamente o que leva à responsabilidade humana, isto é, à emancipação da vontade e do agir político humano no mundo.

Para examinar o sentido do conceito de secularização no pensamento de Hobbes, cabe, todavia, ressaltar que, a despeito da amplitude semântica alcançada pelo conceito, mencionada acima, a secularização é usualmente pensada à luz de duas correntes distintas. A primeira concebe a secularização como uma separação entre religião e política, isto é, entre Estado e Igreja. Tal posição pode ser verificada no pensamento de Hannah
Arendt: "como elemento histórico tangível, a secularização ${ }^{3}$ significa apenas a separação entre Igreja e Estado, entre religião e política; e isto do ponto de vista religioso, implica retorno à antiga atitude cristã de 'dar a César o que é de César e a Deus o que é de Deus' e não uma perda de fé e transcendência ou um novo e enfático interesse nas coisas deste mundo" (ARENDT, 1987, p. 265). Haveria, conforme a autora, uma verdadeira

3 Observa Hannah Arendt "que Maquiavel foi o primeiro a visualizar a ascensão de um domínio puramente secular, cujas leis e postulados de ação eram independentes dos ensinamentos da Igreja, em particular, e, em geral, dos padrões morais, transcendendo 'a esfera dos assuntos humanos" (ARENDT, 1988, p. 29). De fato, as idéias de Maquiavel podem ser pensadas como verdadeiras armas políticas que contribuem para o desgaste dos fundamentos teológico-metafísicos ou a erosão de valores de fé e de autoridade. Ao declarar que a metade das ações humanas é governada pela fortuna e a outra é relegada à esfera de competência dos homens, descortina um mundo contingencial, emancipando a decisão e a responsabilidade da ação humana no mundo (CASTELO BRANCO, 2000, p. 188). Vale dizer, não importa se Maquiavel foi o "primeiro a vislumbrar a ascensão de um domínio puramente secular", já que o suposto encômio poderia ser atribuído a outros que lhe precederam como Dante ou Marsílio de Pádua. O que importa é entender a natureza interna do fenômeno da secularização, isto é, se implica separação ou continuidade entre o espiritual e temporal. Maquiavel, nos Discursos, demonstra o papel desempenhado pela religião para alcançar-se estabilidade na República romana. Na referência ao governo de Numa Pompílio faz comentários laudatórios, já que ele, ao introduzir a "fonte religiosa", conquistava "uma fidelidade sublime" do povo. Além do mais, proclama Maquiavel que, "quando se examina o espírito da história romana, facilmente se reconhece quanto a religião servia para comandar exércitos, restabelecer concórdia entre o povo, velar pela segurança dos bons e fazer com que os maus se envergonhassem da sua infâmia" (MAQUIAVEL, 1950, p. 138). Portanto, Hobbes concordaria plenamente com os dizeres de Maquiavel de que "a observância do culto divino é a fonte da grandeza dos Estados, assim a negligência pelo culto é a causa da ruína dos povos. Onde não existe o temor de Deus, é preciso que o império sucumba ou que seja sustentado pelo temor de um príncipe capaz de substituir a religião" (idem, p. 138-139). Hobbes e Maquiavel sabiam muito bem que, da mesma forma que a Igreja tinha monopólio da fé, o Estado, para não ter duração efêmera, deveria utilizar a religião como poderoso instrumento de dominação. Note-se que a religião - independentemente de seu objeto - talvez seja a dimensão mais importante da crença humana, sem a qual não é possível governar. 
separação entre Igreja e Estado ${ }^{4}$. O rígido caráter da separação entre ambos os domínios reside na improvável transferência de princípios teológicos na formação de categorias seculares, isto é, os conceitos do domínio secular não seriam resultado de gradual conversão de conceitos teológicos. Portanto, a "secularização significa simplesmente a separação de religião e política e isso afetou ambos os lados de maneira tão fundamental que é extremamente improvável que haja ocorrido a gradual transformação de categorias religiosas em conceitos seculares que os defensores da continuidade ininterrupta procuram estabelecer" (ARENDT, 1972, p. 102).

A segunda corrente pode ser representada pelo pensamento de Carl Schmitt. Ao analisar o conceito de soberania, no livro Teologia política, proclama o autor que todos os relevantes conceitos jurídicos e políticos do Estado Moderno são conceitos teológicos secularizados, não apenas em virtude de seu desenvolvimento histórico, mas também em razão de sua estrutura sistêmica. Prossegue salientando que tal reconhecimento é necessário para que se proceda a uma investigação sociológica de tais conceitos. Note-se que o autor concebe a secularização como processo de transferência conceitual do espiritual para o temporal, cujo zênite seria a evolução da teoria da soberania do Estado absolutista ao Estado democrático. O Deus todo-poderoso convertido em legislador onipotente e a exceção na jurisprudência, entendida como Ciência do Direito, como elemento análogo ao milagre na Teologia, seriam exemplos emblemáticos da translação conceitual entre o espiritual e o temporal: precisamente, da transferência de conceitos da Teologia para teoria moderna do Estado (SCHMITT, 1988, p. 36).

Diferentemente da interpretação de Hannah

\footnotetext{
${ }^{4}$ Flávio Pierucci filia-se à corrente representada pelo pensamento de Hannah Arendt, isto é, identifica-se com a vertente que compreende a secularização como separação da religião do Estado. Conforme relata o autor, "a secularização, por sua vez, nos remete à luta da modernidade cultural contra a religião, tendo como manifestação empírica no mundo moderno o declínio da religião como potência in temporalis, seu disestablishment (vale dizer, sua separação do Estado), a depressão do seu valor cultural e sua demissão/liberação da função de integração" (PIERUCCI, 1997, p. 51; grifos no original).
}

Arendt, Jürgen Habermas e Hans Blumenberg contrária à idéia de secularização que guarda em si a continuidade de alguns princípios teológicos -, a análise de Carl Schmitt - enredada na esteira das interpretações continuístas, como, entre outras, a de Reinhart Koselleck, Karl Löwith, Javier Hervada, Ernst H. Kantorowicz e Robert Bellah aponta para a necessidade de repensar o conceito de secularização, não à luz do divórcio entre o sagrado e o profano que ofuscaria a inteligibilidade de alguns modernos conceitos ocidentais, mas por meio do intercâmbio entre ambas as esferas, pois os princípios teológicos continuam operando na formação de categorias epistemológicas de natureza política, histórica, filosófica e jurídica.

Cabe aqui indagar se as interpretações denominadas continuístas não perdem de vista a emergência de uma esfera estritamente secular com seu estatuto próprio, sua autonomia delimitada e seus conceitos políticos independentes da religião. Será que não se constitui em um obstáculo epistemológico deixar de perceber "que a separação entre Igreja e Estado ocorreu, eliminando a religião da vida pública, removendo todas as sanções religiosas da política e fazendo que a religião perdesse aquele elemento político que ela adquirira nos séculos em que a Igreja Católica Romana agia como herdeira do Império Romano" (ARENDT, 1972, p. 103)? Teria o processo de secularização relegado a esfera espiritual ou a religião ao recôndito plano do secreto ou dos assuntos privados? E, por fim, devemos, no plano da investigação dos conceitos políticos e jurídicos do Estado Moderno, cunhar uma definição acerca do conceito de secularização a fim banir de uma vez por todas a religião da ciência ou da teoria política?

Parece-me que responder afirmativamente a tais indagações significaria incorrer em um casuísmo, pois, em primeiro lugar, cristalizar ou buscar definir de maneira unívoca um conceito tão amplo como o de secularização seria esquecer a dimensão genealógica da categoria, cujo campo semântico continua em plena extensão, já que suas acepções vão sendo-lhe culturalmente atribuídas segundo contextos variáveis. Em segundo lugar, a adesão à vertente que prega rígida descontinuidade entre Igreja e Estado e, portanto, rechaça a secularização de conceitos teológicos, obnubila, entre outros fatos, a compreensão do moderno conceito de soberania do Estado na 
acepção representada por Carl Schmitt. Em terceiro lugar, se for possível demonstrar que a categoria da secularização realmente consiste na separação rígida entre Igreja e Estado ou entre religião e política, não se estaria, implicitamente, dizendo, entre outras coisas, que as crenças nas liturgias racional-legais do Estado Moderno em que governam as leis abstratas e genéricas coextensivas a todo corpo social não guardam nenhuma afinidade com a imagem de um Deus ubíqüo, onisciente, onipotente, que estabelece as normas de orientação da ação voltadas para a salvação? Em quarto lugar, compreender a secularização como separação entre Igreja e Estado dá a entender que o suposto "perigo" de uma teocracia ocidental consiste em uma página virada da história. Não criaria uma dificuldade para uma compreensão das teocracias e guerras civilreligiosas que têm lugar em alguns países do Oriente? Os aiatolás, lamas, papas, isto é, os representantes de poderes espirituais, teriam perdido o interesse político nos domínios temporais? No Brasil verifica-se crescimento intenso da bancada evangélica no Congresso Nacional. Enfim, a própria Hannah Arendt parece perder de vista o complexo conceito de secularização, ao asseverar "que a Igreja Católica Romana agia como herdeira do Império Romano", o que poderia ser traduzido sob a ótica - se entendermos o Império Romano como um império secular (em que a religião estava afastada da política ou relegada a um plano privado) - da transferência de princípios universalizantes do secular para o espiritual ou então da cristianização de elementos pagãos ${ }^{5}$.

Uma de minhas hipóteses é que, ao invés de uma separação, poder-se-ia pensar em promiscuidade, intercâmbio ou contínua tensão entre ambas as esferas, sobretudo no que respeita a mútua transferência (herança) de conceitos políticos e jurídicos. Afinal, a racionalidade da estrutura hierárquica das funções, ofícios e

\footnotetext{
5 Talvez Thomas Hobbes estivesse ciente da transferência de princípios pagãos para o espiritual ou da cristianização de elementos pagãos por parte do poder eclesiástico, pois "se alguém atentar no original deste grande domínio eclesiástico verá facilmente que o Papado nada mais é do que o fantasma do defunto império romano, sentado de coroa na cabeça sobre o túmulo deste, pois assim surgiu de repente o Papado das ruínas do poder pagão" (HOBBES, 1983, p. 402; grifos no original).
}

competências delimitadas de bispos, diáconos, papas e cardeais pode ser pensada como um legado da organização burocrática do Império Romano, que talvez devesse ser pesquisada em conformidade com a primeira acepção, de caráter jurídico-político, que assumiria a categoria da secularização: "o de um trânsitus de regularis a canonicus"(MARRAMAO, 1997, p. 17). Hobbes já tinha conhecimento de tal significado 6, " $[. .$.$] ou$ seja a passagem de um religioso 'regular' ao estado 'secular' ou de um modo mais geral, como documentam outros estudos, 'de redução à vida laica' de quem recebeu ordens religiosas ou vive segundo regra conventual" (ibidem).

O fio condutor da investigação proposta neste artigo diz respeito, portanto, à seguinte pergunta dirigida ao Leviatã de Hobbes: implicaria a secularização separação entre o espiritual e o temporal? Mais precisamente, consistiria em uma rígida ruptura entre Igreja e Estado ou haveria uma tensão, em que se revelaria uma troca de princípios criadores de conceitos entre ambos os domínios? Se é esta a questão que define o artigo, antes de tratar da transferência recíproca de conceitos políticos e jurídicos entre ambos os domínios, espiritual e temporal, deve-se explicitar alguns pontos. O intuito deste trabalho é examinar o conceito de secularização no Leviatã de Hobbes, procurando verificar se há separação entre Igreja e Estado ou se há uma continuidade entre ambos os domínios, sobretudo no que respeita à herança de princípios religiosos observada em conceitos políticos e jurídicos. Caso se constate uma continuidade entre ambos os domínios, já que há uma inclinação e suspeita neste sentido, pretendese investigar a transferência conceitual de um ponto de vista unilateral: a transferência de conceitos teológicos à esfera secular, especificamente ao Estado moderno. Se for esse o caminho trilhado, deve-se esclarecer os conceitos a serem perscrutados. Suspeita-se que a moderna concepção de soberania do Estado poderia consistir na transferência de princípios de caráter teológico. Entende-se que afirmações de Carl Schmitt mere-

\footnotetext{
6 Ao questionar por que "o clero regular e secular, seja em que país for, se encontra isento da autoridade de seu reino, em casos criminais?", Hobbes disparava duras críticas, entre outros privilégios, às imunidades de que usufruíam "o Papa, e seus súditos espirituais que residem no território de outros príncipes cristãos" (ibidem, p. 73).
} 
cem exame mais minucioso. O Leviatã pode ser compreendido como uma luta contra a especiosa distinção entre o poder espiritual e o poder temporal, entre o poder da Igreja e o poder do Estado que esmoreceriam ou dissolveriam o Estado. Conforme Hobbes, a "insignificante distinção entre temporal e espiritual" (HOBBES,1983, p. 196) tem de ser proscrita, pois "quando estes dois poderes se opõem um ao outro, o Estado só pode estar em grande perigo de guerra civil ou de dissolução" (ibidem).

\section{O ESTADO E A IGREJA}

Na Filosofia Política de Hobbes, exposta no Leviatã, o sentido assumido pela categoria "secularização" é compreendido na indivisibilidade do poder de um corpo político, isto é, a alma ou soberania do Estado reside na impossibilidade de se distinguir entre poder espiritual e poder temporal (idem, p. 337). A força secularizante da doutrina política do autor é identificada na luta contra a especiosa distinção entre um poder espiritual e um poder secular; tal distinção tem de ser proscrita, pois destrói o Estado e sem ele a humanidade é reduzida à sua condição natural, em que predomina a intermitente possibilidade real de um conflito violento.

A construção política de uma soberania absoluta é a resposta dada por Hobbes à distinção entre o poder espiritual e o poder temporal ou civil, já que, neste mundo, conforme o próprio o autor, não existe outro poder a não ser o temporal. Não importa se o soberano do governo secular é um líder temporal ou espiritual, se é autoridade soberana representativa de um Estado civil ou cristão, pois neste mundo não há outro reino senão o secular. Tal asserção equivale a dizer que Hobbes quer "explicar o Direito e o Estado sem transcender o plano do simplesmente humano" (REALE, 1965, p. 555). A referida afirmação ressalta o caráter secularizante da teoria do Estado de Hobbes, já que fundar o Direito e o Estado em um plano estritamente secular ou simplesmente humano significa romper com a idéia de fundar o poder de dirigir a ação de homens em um plano teológico-metafísico. Ao contrário de um aliciante plano de vida voltado para transcendência comandado por autoridades espirituais, o autor desvela a possibilidade de planejar a vida, isto é, a salvação, em uma dimensão política do agir humano (que somente pode residir em uma esfera intramundana-innerweltlicher). A explicação do Estado e do Direito - enfim, do poder - reside no caráter arbitrário da vontade humana e não em leis eternas e universais. Hobbes refere-se à constituição do Estado, na sua introdução ao Leviatã, como obra de arte, isto é, produto da vontade humana e não de leis divinas. Não se deve perder de vista que o autor somente consegue emancipar um domínio temporal a partir do momento em que reconhece a distinção entre poder espiritual e poder temporal.

Denunciar a distinção entre poder espiritual e o poder temporal ou civil significa dizer que não pode haver distinção entre o poder do Estado e o poder da Igreja, causa principal da guerra civilreligiosa. A Igreja, ao arrogar-se o poder da jurisdição temporal e disputar com o Estado civil a administração da ação humana neste mundo, atua como se fosse um outro Estado: um Estado que se intitula de Estado espiritual em oposição a um Estado temporal (HOBBES, 1983, p. 337). "Mas não existe neste mundo Estado espiritual algum, pois isso é a mesma coisa que o Reino de Cristo, do qual ele mesmo disse não ser deste mundo. Mas existirá no outro mundo, quando da ressurreição, quando os que viveram justamente e acreditaram que ele era o Cristo se erguerem (apesar de terem morrido como corpos naturais) como corpos espirituais. E será então que nosso Salvador julgará o mundo, e vencerá seus adversários, e fundará um Estado espiritual. Entretanto, dado não existirem à face da terra homens cujos corpos sejam espirituais, não pode haver qualquer Estado espiritual entre os homens que ainda existem carnalmente, a não ser que consideremos um Estado os pregadores que têm a missão de ensinar e preparar os homens para sua recepção no Reino de Cristo quando da ressurreição, o que já provei não ser um Estado" (idem, p. 338).

Não resta a menor dúvida: se na superfície deste mundo ou da terra não existem homens com corpos espirituais, não pode haver poder espiritual ou Estado espiritual - também chamada de poder invisível - neste mundo. O reino de homens cujos corpos existem carnalmente é sempre um reino temporal. Repare-se que Hobbes, como bom agnóstico, não nega em nenhuma passagem do Leviatã a existência de um poder espiritual. Seu esforço é no sentido de suprimir a usurpação da jurisdição secular por parte de autoridades eclesiásticas. Para tanto fundamenta suas idéias 
com argumentos extraídos da própria Bíblia Sagrada ${ }^{7}$. O mais persuasivo de todos repete em inúmeras passagens ao longo do Leviatã e é atribuído a Jesus: "O meu reino não é deste mundo" (BÍBLIA. João, 18: 36). Portanto, "nosso Salvador veio a este mundo para ser rei e juiz no mundo vindouro" (HOBBES, 1983, p. 286). O poder espiritual tem jurisdição em um mundo que está por vir.

Hobbes rechaçava com princípios tirados da Bíblia as doutrinas que propugnavam a primazia do poder espiritual em relação ao civil . Utilizavase freqüentemente do que fora narrado nos Velho e Novo testamentos para invalidar as interpretações consideradas idiossincráticas, como era a do Papa Belarmino, entre outros, que defendia: "O poder civil está sujeito ao poder espiritual. Portanto, o detentor do supremo poder espiritual tem o direito de mando sobre todos os príncipes temporais e o de dispor de suas temporalidades" (idem, p. 336). À improcedência da referida interpretação, Hobbes responde mediante a hermenêutica das Escrituras Sagradas $^{8}$ com a exposição de fatos bíblicos que lhe permitem demonstrar que Jesus Cristo nunca exortou os homens a desobedecerem a seus

7 Leo Strauss, ao referir-se às obras Elements (1640), Leviathan (1651) e De cive (1642), comenta que "as três apresentações da filosofia política de Hobbes podem, com um pouco menos de justiça que o trabalho de Spinoza, serem denominadas de tratados teológicos-políticos. Exatamente como Spinoza fez mais tarde, Hobbes com dupla intenção torna-se um intérprete da Bíblia, em primeiro lugar a fim de usar a autoridade das Escrituras a favor de sua teoria, em seguida, e particularmente, a fim de abalar a autoridade das próprias Escrituras" (STRAUSS, 1979, p. 86). Combater a autoridade da Igreja romana mediante suas próprias armas, isto é, com base na exegese e hermenêutica da própria Bíblia é um forte indício a favor da tese da transferência de princípios espirituais ou teológicos à teoria moderna do Estado.

8 Hobbes não somente se utiliza das Escrituras Sagradas para refutar teses que propugnam pela monarquia universal da Igreja em um âmbito temporal, como também se aproveita de textos sagrados para emancipar um domínio secular da tutela da Igreja. Para tanto, extrai princípios sob os quais funda sua teoria dos direitos de quem governa e deveres de quem obedece. Conforme informa Hobbes, "é destas Escrituras que vou extrair os princípios de meu discurso, a respeito dos direitos dos que são na terra os supremos governantes dos Estados cristãos, e dos deveres dos súditos cristãos para com seus soberanos. E com esse fim vou falar no capítulo seguinte dos livros, autores, alcance e autoridade da Bíblia” (HOBBES, 1983, p. 224). soberanos civis. Fazia precisamente o contrário, pois, como "o Reino que reclamava só viria num outro mundo", decidiu ensinar "todos os homens a entretanto obedecerem aos que sentavam na cadeira de Moisés. Permitiu-lhes que dessem a César o seu tributo, e recusou exercer ele mesmo as funções de juiz" (idem, p. 287). A pretensa declaração de Jesus que comprovaria a falta de jurisdição do poder espiritual para tratar de assuntos temporais revela-se, precisamente, no Tributo de César: "Dai, pois, a César o que é de César e a Deus o que é de Deus" (BÍBLIA. Lucas, 21: 25). Hobbes queria provar que Jesus Cristo "nada fez de contrário às leis de César" e tampouco às leis de qualquer autoridade temporal. Demonstrando com tal passagem que a Bíblia sempre exigiu obediência do povo aos senhores seculares em seus domínios, ponderava o uso que papas faziam das palavras de Jesus. A respeito dos dizeres de Jesus Cristo indagava: "como podiam então suas palavras ou ações ser sediciosas, ou tenderem para derrubada do governo civil então existente?" (HOBBES, 1983, p. 287). Refutando interpretações, como a do Papa Belarmino, Hobbes lança mão de princípios teológicos para secularizar ${ }^{9} \mathrm{o}$ Estado. E ao proceder desta forma está separando o Reino de Deus do Reino dos Homens, a civitas dei da civitas hominis, o Reino das Luzes do Reino das Trevas, o poder invisível (espiritual) do poder visível (temporal), a Igreja do Estado. Mas, de imediato, deve-se salientar que, embora Hobbes separe o espiritual do temporal pois o espiritual trata de assuntos pertinentes a um mundo vindouro -, a separação proposta tem um caráter peculiar. Para dar cabo à disputa política do Estado e da Igreja, o autor submete a Igreja ao poder estatal. O Estado absolutista de Hobbes suprime qualquer forma de poder ou instituição autônoma - seja econômica, religiosa ou de qualquer outra espécie - capaz de obstar seu direito político de orientar a ação no mundo; em outras

\footnotetext{
9 Ao definir a secularização como separação entre Igreja e Estado, Hannah Arendt observa que tal separação não significou a perda da fé e sequer trouxe os homens de volta a este mundo, isto é, ao invés de tornarem-se mais satisfeitos na relação com o mundo e outros homens, eles individualizaram-se, alienaram-se do mundo. Diz Arendt: "Mesmo que admitíssemos que a era moderna teve início com um súbito e inexplicável eclipse da transcendência, da crença de uma vida após a morte, isto não significa que esta perda houvesse lançado os homens de volta a este mundo, mas para dentro de si mesmos" (ARENDT, 1987, p. 265266).
} 
palavras, seu direito de resolver qualquer espécie de litígio ou conflito que ameace a paz intestina do corpo político. De fato, no âmbito político, "monarcas procuravam extinguir ou neutralizar todas instituições autônomas (mesmo o mercantilismo enquanto sistema econômico, está submetido ao planejamento e à condução estatal). Também as questões relativas à religião e à Igreja foram tratadas em função de sua utilidade, fosse num âmbito de uma igreja de Estado ou de uma tolerância oportuna" (KOSELLECK, 1999, p. 20). No que respeita à teoria do Estado de Hobbes, aduzida no Leviatã, as questões atinentes à religião e à Igreja não foram tratadas no âmbito de uma tolerância oportuna e sim no âmbito de uma Igreja de Estado. $\mathrm{Na}$ esfera pública compete à autoridade soberana representativa do Estado determinar qual religião deve ser adotada pelos cidadãos. Conseqüentemente, cabe ao comando estatal determinar o que é necessário à salvação, não só neste mundo, como também em um mundo vindouro. Daí advém a necessidade de a autoridade do corpo político indicar com precisão a religião ${ }^{10}$ de seu domínio e ordenar aos particulares que a ostentem publicamente em um só culto, o que equivale ao poder de ordenar o culto público. Portanto, na filosofia política de Hobbes, não há espaço para tolerância oportuna, pois "quando são permitidas muitas espécies de cultos, resultantes das diferentes religiões dos particulares, não se pode dizer que haja qualquer culto público, nem que o Estado tenha qualquer religião" (HOBBES, 1983, p. 217).

O inimigo principal do Leviatã eram homens pertencentes a igrejas e seitas, cujo principal problema residia no fato de pretenderem-se profetas ${ }^{11}$ de Deus (idem, p. 257), isto é, repre-

\footnotetext{
10 A divisão da Igreja romana esmoreceu a quase inabalável autoridade papista, o que abriu caminho para que alguns líderes seculares usurpassem a autoridade eclesiástica de determinar em seus domínios qual seria a religião oficial do reino, exatamente de acordo com o princípio secularizante cujus regio, ejus religio (a religião é de quem é a região), porque "quem não tem reino não pode fazer leis" (HOBBES, 1983, p. 309). Portanto, quem não tem reino não pode ordenar a conduta humana, nem tampouco deter o monopólio acerca da crença dos súditos.

11 Ao alertar para o perigo dos pretensos profetas, ensinava Hobbes que "é preciso ser-se muito circunspecto e cuidadoso ao obedecer à voz de homens que pretendem ser profetas e exigem que obedeçamos a Deus da maneira que eles, em nome de Deus, nos dizem ser o caminho da felicidade" (HOBBES, 1983, p. 256).
}

sentantes do poder espiritual na Terra. Profetas, bispos, papas, monges, pastores derivavam seu poder, direitos e funções da imediata autoridade de Deus, o que constituía uma ameaça à unidade e segurança do Estado, uma vez que não deviam obediência ao soberano civil. Agindo desta forma, denunciava Hobbes, "eles estão negando receber do Estado civil sua autoridade, estão subrepticiamente tirando a coleira de sua sujeição civil, contrariamente à unidade e defesa do Estado" (idem, p. 319). A fim de enfrentá-los o autor separa o que é de César, isto é, a esfera temporal, política, da esfera espiritual, religiosa, cuja jurisdição é de Deus, e pertence a outro mundo. Mas por que se atribui a tal separação um caráter peculiar? Porque para separar a Igreja do Estado Hobbes não pode isolar a Igreja. O autor está ciente de que a Igreja detém um dos maiores poderes. Trata-se da sedução ou persuasão ${ }^{12}$, arte mediante a qual a Igreja consegue obter o monopólio da crença de um povo e governar suas ações neste mundo por meio de promessas de salvação em um mundo vindouro. Hobbes, ao alertar para o perigo das promessas de salvação em outro mundo, proclama que "quem pretende ensinar aos homens o caminho para tão grande felicidade pretende governá-los, quer dizer, dirigi-los e reinar sobre eles, pois é uma coisa que todos homens naturalmente desejam, portanto isso merece ser suspeito de ambição e impostura; conseqüentemente, tal pretensão deve ser examinada por todos,

\footnotetext{
12 Hobbes, ao explicitar, de acordo com as Sagradas Escrituras, a função dos representantes de Deus na Terra, revela que a tarefa que lhes compete consiste na persuasão, não de um suposto poder coercitivo concedido pelo Salvador para punirem, neste mundo, incréus, mas para "ganhar os homens para obediência, não pela coerção e pela punição, mas pela persuasão" (HOBBES, 1983, p. 293). O escopo da persuasão de ministros cristãos reside na "evangelização, isto é, a proclamação de Cristo e a preparação de sua segundo vinda; tal como a evangelização de São João Batista era uma preparação para a primeira vinda". Conduzir a persuasão de tal maneira é comparado, conforme o autor, pelo Salvador à pesca, pois conduzi-la sob ameaça consistiria na caça, uma vez que os representantes do Reino de Deus não são "caçadores de homens, e sim pescadores de homens" (idem, p. 293-294). Repare-se que, de acordo com o autor, o poder de persuasão da Igreja requer um controle, uma vez que se utilizando deste poder a Igreja chegou a exercer neste mundo seu pretenso direito de caça ou jus puniendi sob argumento de punir quem quer que transgredisse as leis de Deus. Os tribunais religiosos da Santa Inquisição constituem a maior prova disso.
} 
antes de lhe prestarem obediência, a não ser que tal já lhes tenha sido prestada, na instituição de um Estado, quando o profeta é o soberano civil, ou é autorizado pelo soberano civil" (idem, p. 256).

Com o intuito de dirimir o problema da especiosa distinção entre espiritual e secular, o autor subordina a Igreja ao Estado e transforma-a em um instrumento de poder político secular. Nisso reside a possibilidade do governante, se porventura julgar conveniente à ordem do Estado, investir-se das funções de um profeta ou um "vice-rei de Deus na terra" (idem, p. 257).

Neutralizar os conflitos que põem em risco a incolumidade de um corpo político significa que não haja poder senão o poder do Estado. Daí advém o poder absoluto: por isso, a partir do conceito de soberania absoluta dificilmente se vislumbraria o direito de resistência dos súditos diante do representante do Estado, um Deus mortal (idem, p. 106). A autoridade representante da soberania temporal é um soberano civil e, ao mesmo tempo, um pastor, pois a autoridade soberana também é chefe da Igreja do Estado. Portanto, "em todo Estado cristão o soberano civil é o supremo pastor, que tem a seu cargo todo o rebanho de seus súditos" (idem, p. 318).

$\mathrm{Na}$ sua teoria da indivisibilidade do poder Hobbes relega a atuação da Igreja como Estado a um outro mundo. A Igreja com pretensões políticas é um Estado sem reino, sem tribunal, sem poder coercitivo, portanto tem de ser absorvida pela esfera temporal para evitar a desobediência dos súditos.

Para elidir a distinção entre o poder espiritual e o poder temporal, Hobbes submete o primeiro ao segundo. A emancipação de um domínio estritamente secular das rédeas do poder da Igreja implica subordinar a Igreja ao Estado, convertendo a instituição espiritual em um instrumento de controle da ordem interna do Estado. A Igreja passa a ser mais um instrumento a serviço dos interesses políticos do Estado. Em outras palavras, o autor, a fim de neutralizar o conflito entre o poder espiritual e o temporal, incorpora a Igreja ao Estado. Assim, o autor não separa poderes, mas unifica-os nas mãos do domínio secular; "a partir daí, portanto, ficam inseparáveis o direito de regular quer a política, quer a religião" (ibidem, p. 282). Conforme Hobbes, a religião não é estranha à política, pois não somente a integra, como, principalmente, constitui-se em um eficaz instrumento político de dominação. Para o autor, a religião como arma política indispensável à arte, mediante a qual se constitui e mantém um corpo político, não era novidade na história das civilizações. $\mathrm{O}$ ato de incutir na mente do povo a crença em preceitos da religião, inventados por homens mas divulgados como ditames de algum deus, eram técnicas de dominação utilizadas pelos "primeiros fundadores e legisladores de estados entre os gentios, cujo objetivo era manter o povo em obediência e paz", fazendo que "suas leis fossem mais facilmente aceites" (idem, p. 70). Talvez seja essa umas das passagens mais importantes do Leviatã. Nela percebe-se como é indispensável à arte de governar o monopólio da crença do povo e como o governante deve tirar partido da tendência do gênero humano à irracionalidade da credulidade em poderes invisíveis (idem, p. 263) ou em discursos herméticos e univesalizantes como, muitas vezes, nos dias de hoje, são aqueles proferidos pelos profetas da deusa Economia.

$\mathrm{Na}$ teoria constitucional hobbesiana a Igreja está separada do Estado na medida em que não se constitui mais como poder visível, isto é, deste mundo. Não representa mais nenhuma ameaça aos interesses políticos do soberano deste mundo. A Igreja está separada do Estado em face do exercício de seu poder pertencer a mundo vindouro; enquanto o dia do juízo final não vem, deve-se dar a César o que é de César e a Deus o que é de Deus. E o que é de Deus não pertence a este mundo, seu reino e seu poder de judicatura estão separados, aguardando sua soberania que ao outro mundo pertence. Conclui-se "que a autoridade dos soberanos terrenos não deverá ser derrubada antes do dia do juízo" (ibidem, p. 298), pois "nosso Salvador veio a este mundo para poder ser rei juiz num mundo vindouro" (ibidem, p. 286). Portanto, a autoridade dos soberanos terrenos em seus domínios é plena e o governo da religião faz parte do governo da política. Enquanto o que é de Deus não vem, isto é, o seu efetivo governo, dai, pois, tudo a César; em outras palavras, entregue à autoridade temporal o poder de regular a política bem como a religião.

Como neste artigo pretende-se buscar compreender as idéias de Hobbes de acordo com 
seus próprios termos ${ }^{13}$, cumpre esclarecer que se referir à secularização como separação entre Estado e Igreja é inadequado. Ao discorrer sobre a relação entre Estado e Igreja, Hobbes não mencionou a palavra "separação". Refere-se a uma distinção entre poder espiritual e poder temporal que em sua teoria política é identificada à ruína do Estado, pois a distinção representa a disputa política de representantes de distintos poderes que confundem os homens, ofuscando a compreensão quanto a quem os governa e, portanto, a quem devem obediência em troca de proteção. Bobbio, influenciado ${ }^{14}$ pela interpretação de Carl Schmitt no livro The Leviathan in the State Theory of Thomas Hobbes: Meaning and Failure of Political Symbol, viu corretamente que "Hobbes, ao reagir à anarquia provocada pelas guerras civis de religião [...] propõe eliminar o conflito entre as várias igrejas ou confissões eliminando a causa mais profunda do conflito, isto é, a distinção entre o poder do Estado e o poder da Igreja. Ele quer na verdade que não haja outro poder a não ser o do

13 A despeito de buscar entender as idéias de um autor de acordo seus próprios termos constituir-se em um intransponível obstáculo hermenêutico, o que se busca fazer é uma análise textual do significado dos poderes invisíveis (espirituais) e poderes visíveis (temporais) no Leviatã de Hobbes. Ao fazê-lo está-se investigando o conceito de secularização na referida obra do autor. Contudo, é importante lembrar, em conformidade com a metodologia da Begriffsgeschichte de Koselleck, que um conceito de tal amplitude semântica, como é o caso do conceito de secularização, além de ser um indicador de mudanças políticosociais que ocorreram na história, seu emprego é reflexo de lutas políticas que produzem efeito no plano históricosocial (KOSELLECK, 1985, p. 74ss.). Portanto, caso se aplicasse esta metodologia, por meio de investigação de um conceito-chave, poder-se-ia alcançar sua repercussão em âmbito histórico-social, mesmo partindo apenas de uma análise textual do conceito.

14 No final de seu livro Thomas Hobbes, Bobbio destaca três livros sobre Hobbes. Sobre o primeiro deles, da autoria Carl Schmitt, observa que "esse novo ensaio sobre Hobbes pode precisamente ser considerado uma tentativa inteligente, realizada por um dos juristas mais cultos e originais que vivem atualmente na Alemanha, de tomar contato com o velho e misterioso mito do Leviatã, para apresentar um balanço global do mesmo, indicando os vários temas da obra que depois atuaram na formação do Estado moderno" (BOBBIO, 1991, p. 193).
Estado e que a religião seja reduzida a um serviço" (BOBBIO, 1995, p. 37) ${ }^{15}$.

Não se deve perder de vista que é justamente o reconhecimento da distinção entre o poder espiritual e poder temporal que permite a Hobbes diluir o poder da Igreja unindo-a ao Estado. Como se viu, é a partir da referida distinção, causa principal da guerra civil religiosa, que autor forja seu conceito de soberania, cujo traço principal reside na indivisibilidade do poder, pois "é impossível entender que um poder tenha poder sobre um outro poder, ou que um poder possa ter direito de mando sobre outro, visto que sujeição, mando, direito e poder não são acidentes de poderes e sim de pessoas" (HOBBES, 1983, p. 336). Se o poder e o Direito constituem-se em acidentes de pessoas, isto é, são fatores derivados da vontade humana, como pode um poder espiritual, proveniente da vontade divina, procurar sujeitar o poder temporal dos homens? O poder espiritual que pretende manifestar-se na Terra consiste em uma ficção, pois encobre a dimensão política do agir humano. Não é Deus e nem tampouco são anjos ou demônios que governam este mundo, mas são homens que lutam para governar homens. Sujeição, mando, Direito e poder são elementos constitutivos da disputa política que homens não podem travar senão em um âmbito secular.

Se para Hobbes o monopólio da decisão política pertence à autoridade soberana do Estado, não é de estranhar-se que o governo da religião esteja consolidado no referido monopólio ${ }^{16}$. Na teoria da indivisibilidade do poder de Hobbes não há espaço para qualquer instituição ou homens unidos em uma pessoa com autonomia que não seja o próprio Estado. Se a Igreja for uma pessoa

\footnotetext{
15 No mesmo sentido, constata Leo Strauss que a "atitude pessoal de Hobbes em relação à religião positiva sempre foi a mesma: a religião deve servir ao Estado e será prezada ou desprezada de acordo com os serviços ou desserviços prestados ao Estado" (STRAUSS, 1979, p. 89).

16 O monopólio da decisão política inclui o monopólio da religião dos súditos, pois a política consiste na esfera arbitrária e falível do agir humano (secular) da qual, para Hobbes, a religião é inseparável, já que a crença nos poderes invisíveis ou espirituais não é legada aos homens por um Deus ou poder superior, mas existe nos próprios homens, pois "verificando que só nos homens encontramos sinais ou frutos da religião, não há motivo para duvidar que a semente da religião se encontra também apenas no homem" (HOBBES, 1983, p. 65).
} 
dotada de autoridade, isto é, capaz manifestar sua vontade, promulgando leis que orientam a ação externa de súditos, ela é a mesma coisa que um Estado cristão. Por isso, o direito ao controle da política inclui o direito de determinar qualquer questão pertinente à manifestação externa das crenças religiosas dos súditos. O monopólio da decisão política nas mãos do soberano do Estado pressupõe a consolidação do direito político e eclesiástico. Daí o autor professar que, "dada essa consolidação do direito político e eclesiástico nos soberanos cristãos, fica evidente que eles têm sobre seus súditos toda espécie de poder que pode ser conferido a um homem, para governo das ações externas dos homens, tanto em política como em religião; e que podem fazer as leis que melhor the afigurarem para o governo de seus súditos, tanto na medida em que eles são o Estado como na medida em que eles são a Igreja, pois o Estado e a Igreja são os mesmos homens" (idem, p. 321).

Conclui-se que na teoria do Estado de Hobbes não há separação entre Igreja e Estado, entre religião e política, uma vez que ambas as matérias são da competência da autoridade soberana do Estado. Se há homens unidos em uma pessoa, representados pela autoridade de uma assembléia soberana ou de um único soberano, tal pessoa denomina-se Estado. Portanto, fica claro que na teoria constitucional do autor "não só não há separação entre Igreja e Estado, como Igreja e Estado são a mesma coisa, são 'dois nomes diferentes' - diz Hobbes - da mesma coisa, tendo a denominação de Estado 'enquanto consta de homens, e de Igreja enquanto consta de cristãos'. Desse modo, a teoria da indivisibilidade do poder, fundada na convicção de que o poder soberano ou é o único ou não é soberano, desemboca numa total conversão da Igreja em instituição do Estado, bem como na afirmação sem atenuantes - da religião de Estado" (BOBBIO, 1991, p. 56).

A Igreja transforma-se em um instrumento do qual dispõe o governante do Estado; passa a ser uma instituição a serviço dos interesses da autoridade soberana. Na teoria política de Hobbes, o monopólio estatal da crença religiosa significa um indispensável mecanismo de controle das paixões de homens, cujo traço principal consiste em atribuir significado ao ininteligível, a manifestar uma devoção pelos poderes invisíveis que se teme, pelas profecias, pelas sedutoras promessas de salvação. O monopólio da decisão política do governante do Estado inclui o controle das manifestações externas das crenças religiosas dos governados.

A partir do que acima foi mencionado, fica claro que a tão comentada distinção entre o poder espiritual e o poder temporal tem de ser eliminada para que se alcance paz, ordem, proteção e obediência no interior de um corpo político. Se o governo da religião, isto é, o governo espiritual não estiver consolidado no governo da política não é possível secularizar o Estado, pois retorna-se às disputas entre espiritualistas e temporalistas, o que representa um retorno à guerra civil-religiosa. Por essa razão, "não é legítimo que qualquer súdito ensine doutrinas proibidas pelo governante de Estado e da religião. Esse governante tem que ser um só; caso contrário segue-se necessariamente a facção e a guerra civil no país entre Igreja e o Estado, entre os espiritualistas e os temporalistas, entre a espada da justiça e o escudo da fé. E o que é mais ainda, no próprio coração de cada homem, entre o cristão e o homem" (HOBBES, 1983, p. 277).

\section{DIREITO E MORAL}

Hobbes não era ingênuo quanto à ambiciosa e, ao mesmo tempo, árdua missão da qual se investira em sua teoria política. Embora ressaltasse a importância do método, não só no estudo da geometria, mas também no da política, ao comparar ambas áreas do saber, dizia: "a política é dos dois estudos o mais difícil" (idem, p. 209). Esse comentário não era trivial. A fim de forjar seu conceito político de soberania absoluta do Estado - imprescindível à garantia de uma paz duradoura no interior de um corpo político - seria necessário seguir o método que indicasse as causas da guerra e da paz. Daí o autor não tergiversar de uma das principais questões que desencadeavam os conflitos religiosos: "é uma questão muito disputada entre as diversas seitas da religião cristã de onde as Escrituras tiram sua autoridade" (idem, p. 230). O problema residia na dificuldade em fundamentar e constituir uma autoridade capaz de governar ações provenientes da multiplicidade de crenças existentes entre os homens que viviam sem um poder visível ou "comum capaz de os manter a todos em respeito" (ibidem, p. 75) ${ }^{17}$. Ao

17 É importante salientar que a despeito dos elogios (RIBEIRO, 1991, p. 77) à tradução do Leviatã para o português, realizada por João Paulo Monteiro e Maria Beatriz Nizza Silva (HOBBES, 1983), Renato Janine Ribeiro ob- 
exteriorizar a pluralidade de suas respectivas crenças, sobretudo religiosas, os homens radicalizavam suas ações, que passavam a ser ditadas pela constante tensão de uma Bellum omnium contra omnes, isto é, "uma guerra de todos contra todos", em "que as noções de bem e mal, justiça e injustiça, não podem aí ter lugar (ibidem). Na tentativa de lograr uma resposta, Hobbes discernia, acuradamente, o problema. Dizia: "quando se levanta a questão de nossa crença, dado que uns são levados a acreditar por uma razão e outros por outras diferentes, não é possível dar uma resposta geral válida para todos" (idem, p. 231). Decidido a resolver o problema, formulou-o da seguinte maneira: por meio de que autoridade as crenças tornam-se leis? Ou então, como dizia o próprio autor ao referir-se às crenças nas Escrituras Sagradas: "a formulação correta da questão é por que autoridade elas são tornadas leis" (ibidem). A questão é crucial na medida em que, para o autor, as leis das Escrituras Sagradas não diferem das leis da natureza ${ }^{18}$ (ibidem). Em outras palavras, "as leis de Deus portanto nada mais são do que as leis de natureza" (idem, p. 342). Mas leis de natureza, bem como leis bíblicas ou divinas, enquanto não forem reconhecidas por uma autoridade não são leis; consistem em preceitos morais, impõem um dever ser sem amparo externo,

serva que Hobbes não menciona "um poder comum capaz de manter a todos em respeito", mas, sim, "um poder comum capaz de manter a todos em reverente temor". $\mathrm{Na}$ versão original do Leviathan, editada pela Penguin Group, entre outras passagens, no capítulo XVII, por exemplo, aludindo aos homens proclama Hobbes que "there is no visible Power to Keep them in awe" (HOBBES, 1985, p. 223), isto é, "não há um poder visível capaz de os manter em reverente temor" e não como aparece na referida tradução para português "não há um poder visível capaz de os manter em respeito" (HOBBES, 1983, p. 103). Esse comentário justifica-se na medida em que a referida tradução pode levar a uma interpretação equívoca das idéias de Hobbes, pois o fundamento do Estado reside, sobretudo, em uma paixão: o medo ou temor da morte violenta. Logo trocar temor por respeito significa dar uma dimensão inadequada à paixão mais importante na gênese do Estado moderno, já que "a tradução usual de Keep all in awe, 'manter todos em respeito', debilita essa paixão" (RIBEIRO, 1999, p. 253).

18 Constata-se, a partir da referida questão, como a secularização consiste em uma chave imprescindível para perceber-se como Hobbes vai distanciando-se da doutrina jusnaturalista e, paulatinamente, inaugurando o positivismo jurídico. indicam-nos as regras do bem e do mal, virtudes morais e vícios imorais (idem, p. 95). Repare-se que, a fim de compreender como Hobbes resolve o problema mencionado acima, isto é, por meio de que autoridade a crença nas Escrituras tornase lei, é fundamental ater-se à definição que o autor tem de leis de natureza ou leis naturais: "pois sendo as leis naturais eternas e universais são todas elas divinas" (idem, p. 172).

A definição que confere ao jus naturalis, ou direito de natureza, ajuda-nos a compreender o que o autor entende por lex naturalis, ou lei de natureza. $\mathrm{O}$ direito de natureza consiste na liberdade que cada homem possui de utilizar seu poder de fazer ou deixar tudo aquilo que julgar necessário à preservação de sua própria natureza. Em outras palavras, tal direito permite adequar qualquer meio que a razão de cada um julgar necessário ao fim da autopreservação. Já as leis de natureza são compreendidas como regras morais, determinadas pela razão, por meio das quais "se proíbe a um homem fazer tudo o que possa destruir sua vida ou privá-lo dos meios necessários para preservá-la, ou omitir aquilo que pense poder contribuir melhor para preservá-la" (idem, p. 78). Em seguida, ao concluir sua distinção entre direito e lei, repreende autores provavelmente pertencentes a uma tradição jusnaturalista de pensamento. Proclama que, "embora os que têm tratado deste assunto costumem confundir jus e lex, o direito e a lei, é necessário distingui-los um do outro. Pois direito consiste na liberdade de fazer ou de omitir, ao passo que a lei obriga ou determina uma dessas coisas" (ibidem). De acordo com Koselleck, para Hobbes, "todos os teólogos, filósofos da moral e juristas constitucionais teriam falhado, pois suas doutrinas apoiavam os direitos de determinados partidos e, portanto, incitavam à guerra civil, em vez de ensinar um direito que estivesse acima dos partidos" (KOSELLECK, 1999, p. 26). Ora, de certo modo, poder-se-ia declarar que Hobbes eleva-se acima dos interesses partidários de seu tempo, pois, ao propugnar por paz duradoura no interior de um corpo político e elegê-la como ponto de partida incondicional ou premissa de sua doutrina política, não a justifica por meio de alguma seita, partido ou religião. $\mathrm{O}$ autor procura justificar a paz como um ditame da razão, como uma regra geral passível de validade, capaz de ser fundada no consenso e, portanto, como possibilidade de obter amparo externo de uma 
única autoridade ou da autoridade de uma assembléia soberana constituída. Hobbes parece convencido de que a paz está acima do interesse pessoal de cada um, "pois todos os homens concordam que paz é uma boa coisa" (HOBBES, 1983, p. 94), independentemente da pluralidade de crenças de cada um. Aliás, durante a guerra civil religiosa, "no vaivém dos perseguidores e perseguidos, que trocavam constantemente os papéis de vítima e de carrasco, não sobreviveu quem se manteve fiel à sua crença, mas quem buscou a paz pela paz" (KOSELLECK, 1999, p. 23). Por isso a finalidade da instituição do Estado não é senão "a paz e a defesa de todos" (HOBBES, 1983, p. 109), independentemente das crenças ou da consciência de cada um. Se porventura lograrse alcançá-la, adquire-se o status de um agrupamento de homens unidos na figura de uma pessoa representante da vontade de todos ${ }^{19}$. Assim, todas as crenças, isto é, todas as consciências privadas dos súditos submetem-se à consciência pública ${ }^{20}$, representada pela exclusiva vontade de quem detém o poder soberano. As convicções internas de cada súdito só podem ser exteriorizadas na medida em que não entrem em conflito com a vontade do soberano, representativa da moral pública, manifestada e garantida por meio de leis positivas. Aliás, tais leis opõem-se às leis de natureza ou às sobrenaturais, pois "não existem desde toda eternidade e foram tornadas leis pela vontade daqueles que tiveram o poder soberano sobre os outros. Podem ser escritas ou então dadas a conhecer aos homens por outro argumento da vontade de seu legislador" (idem, p. 171).

\footnotetext{
19 Hobbes, em oposição àqueles que defendiam formas de governo fundadas em leis sobrenaturais ou naturais, propugnava o maior dos poderes humanos "composto pelos poderes de vários homens, unidos por consentimento numa só pessoa, natural ou civil, que tem o uso de todos os seus poderes na dependência de sua vontade: é o caso do poder de um Estado" (HOBBES, 1983, p. 53). Aqui interessa salientar que Hobbes não deriva o seu direito constitucional do Estado da vontade divina ou de leis naturais eternas e universais, mas de um consentimento dos homens. Assim, Hobbes, na sua teoria do Estado, introduz um conceito moderno de legitimidade - daí a importância da força coercitiva do soberano para fazer valer o cumprimento da palavra dada pelos súditos, cujo caráter é irrevogável.

20 Note-se como a noção de consciência pública pode ser traduzida pela idéia de razão de Estado.
}

No que respeita às leis de natureza, embora lance mão da terminologia comum à sua época, típica de uma tradição jusnaturalista de pensamento, Hobbes prefere chamá-las de regras morais ou teoremas estabelecidos pelos ditames da razão. Portanto, o autor considera inadequada a designação de leis de natureza, porque a "estes ditames da razão os homens costumam dar o nome de leis, mas impropriamente. Pois eles são apenas conclusões ou teoremas relativos ao que contribui para defesa de cada um. Ao passo que lei em sentido próprio é a palavra daquele que tem direito de mando sobre outros" (idem, p. 95). Isso ocorre em virtude de a lei somente possuir o poder de obrigar a fazer ou deixar de fazer alguma coisa a partir do momento em que alguma autoridade soberana reconheça-a e tenha o poder de exigir seu cumprimento; caso contrário, a lei de natureza ou lei natural refere-se apenas às intenções e não às ações do indivíduo. E tal justifica-se porque na teoria do Estado de Hobbes não só "pertence à soberania o poder de prescrever as regras", mas também "pertence ao poder soberano a autoridade judicial, quer dizer, o direito de ouvir e julgar todas as controvérsias que possam surgir com respeito às leis, tanto civis quanto naturais, ou com respeito aos fatos" (idem, p. 110). Deve-se lembrar que o direito de mando sobre os outros deriva do consentimento dos governados e não das leis naturais ou divinas; aliás, o "direito de todos os soberanos deriva originariamente do consentimento de cada um dos que irão ser governados" (idem, p. 335).

Conforme o autor, as leis naturais ou de natureza, tratando-se, na verdade, de regras morais acerca do bem e do mal, somente "obrigam in foro interno, quer dizer, impõem o desejo de que sejam cumpridas, mas in foro externo, isto é, impondo um desejo de pô-las em prática, nem sempre obrigam" (idem, p. 94). Eis a questão fundamental: Hobbes distingue foro íntimo de foro externo ${ }^{21}$, interior de exterior, consciência ou intenção de

\footnotetext{
21 Aqui cabe desfazer equívoco de interpretação histórica. Tem sido trivial assegurar que "foi na última fase da Escola do Direito Natural que surgiu a primeira doutrina explícita e deliberada sobre os critérios distintivos entre o mundo jurídico e o mundo moral, o que se deve atribuir aos méritos de Thomasius (1655-1728) [...], notadamente em sua obra capital, Fundamenta Juris Naturae et Gentium, publicada em 1705" (REALE, 2000, p. 653). Ora, em primeiro lugar, parece-me, que o afã em atribuir-se rótulos às idéias de autores é temerário, já que, entre outros, tanto
} 
ação. Proclama que toda lei que obriga apenas no âmbito do foro íntimo, isto é, moralmente, pode ser violada, quer seja na inconformidade da ação à lei moral, quer seja na conformidade da ação à lei moral ou natural. Conforme relata o próprio autor, "todas as leis que obrigam in foro interno podem ser violadas, não apenas por um fato contrário à lei, mas também por um fato conforme a ela, no caso de seu autor considerá-lo contrário. Pois embora neste caso sua ação seja conforme à lei, sua intenção é contrária à lei, o que constitui uma violação quando a obrigação é in foro intimo" (ibidem).

Nessa passagem Hobbes revela-nos que as leis naturais, isto é, morais, dizem sempre respeito às intenções e por isso podem sempre ser violadas mesmo em situações em que a ação seja conforme à lei, pois não há como exercer um controle externo da consciência ou das intenções. As leis morais levam os homens a julgarem suas ações somente no âmbito da intenção e não do efeito que delas possa advir. Torna-se patente que somente "se pode julgar a conduta através de ações externas, ações estas que só podem tornar-se ilegítimas quando são contrárias à lei do Estado" (idem, p. 303).

Tal passagem revela-nos que Hobbes distinguia na conduta humana dois planos: o interno, precisamente o da consciência, e o externo, plano por meio do qual a ação projeta-se no mundo e torna-se passível de julgamento por terceiros. Ao fazê-lo, o autor já discernia entre Moral e Direito 22 . Enquanto a ação tramita no âmbito da intenção, isto é, do foro íntimo, cada um é juiz de sua própria conduta e tal julgamento desenrola-se no campo da moral privada. Por outro lado, no momento em que a conduta não se limita ao âmbito da moral e, portanto, exterioriza-se, o foro competente para

Hobbes, como Hugo Grotius, Maquiavel e Thomasius estão enredados na esteira dos autores que buscam distinguir não só entre política e religião, mas, também, precisamente, entre direito e moral. Em segundo lugar, é bom salientar que Hobbes (1588-1679), no Leviatãa, de 1651, portanto mais de meio século antes de Thomasius, distingue não só entre foro íntimo e foro externo, mas entre Direito e Moral.

22 Miguel Reale, no livro Lições preliminares de Direito, abre o capítulo V, cujo título é Direito e Moral, proclamando que "encontramo-nos, agora, diante de um dos problemas mais difíceis e também dos mais belos da Filosofia do Direito, o da diferença entre a Moral e o Direito" (REALE, 1979, p. 41). julgá-la denomina-se Direito. Daí o autor esclarecer que só é possível julgar a conduta humana a partir de ações externas, pois são visíveis e podem ser objeto do mundo do Direito, cuja existência depende da constituição de uma vontade soberana dotada de poder coercitivo.

Hobbes tece argumentos para distinguir a Moral do Direito, o interior do exterior, o público do privado, o crime do pecado, enfim a fé da confissão. Mas qual é a sua finalidade? De que modo tais distinções conectam-se ao problema que o autor busca solucionar, isto é, por meio de que autoridade as crenças nas Escrituras Sagradas tornam-se leis?

Hobbes, durante a guerra religiosa de seu tempo, via reinar conflitos violentos em virtude da luta pela supremacia das crenças de cada partido, seita e igreja. Cada homem invocava sua consciência para lutar pela sua religião, seus valores morais, isto é, pela supremacia de seu juízo em relação a todas as matérias. Se cada indivíduo invocava ou exteriorizava o seu foro íntimo para defender seus valores, seus objetos de paixão, não é de se surpreender que, em razão da pluralidade de crenças proveniente da natureza humana, predominasse a discórdia.

Ao discorrer sobre a condição natural da humanidade, Hobbes retrata a psicologia, isto é, as aversões e os desejos, os distintos temperamentos do homem fanático religioso ${ }^{23}$ que se comporta como lobo diante de outro, pois, ao invocar suas convicções de foro íntimo, sua crença, sobretudo sua religião, busca reconhecimento e respeito de outro homem. Todavia, cada um vive isolado ou atomizado em função de estar projetado dentro de seu mundo interior ou imaginário e por isso o cenário do estado de natureza, no qual não há poder comum capaz de manter a todos em reverente temor, é composto de homens, cujo traço primordial consiste na pluralidade de consciências privadas que, ao exteriorizarem-se, dão origem à emulação e ao conflito (idem, p. 111). Como se vê, no momento em que desce do pedestal de seu

23 Observa Hume "que a história nos ensina que houve fanáticos religiosos desta espécie na Inglaterra nas guerras civis" (HUME, s/d, p. 49). Creio que a relevância do comentário do autor reside no fato de Hobbes transladar para o estado de natureza as paixões de homens que lutavam na guerra civil-religiosa para defender suas convicções de foro íntimo. 
solitário mundo imaginário, o homem, ao exteriorizar sua consciência privada, busca que outro homem reconheça seu valor, sua religião. Porém, nesse encontro, o outro homem também busca o reconhecimento de suas convicções de foro íntimo, seu valor ou seus valores - como, onde quer que haja homens, há diversidade de convicções privadas - portanto, não há entendimento, respeito e sequer reconhecimento. $\mathrm{O}$ encontro de homens ávidos em invocar ou exteriorizar sem limites suas convicções pode levá-los à ignomínia de um violento conflito corporal, precisamente porque cada um é juiz em causa própria, e suas crenças principalmente sua religião - devem ser reconhecida por todos; se porventura não o for, deve-se destruir o inimigo. Daí se infere que "as convicções levavam a ações cada vez mais radicais, como o objetivo de aniquilar o inimigo, não só externamente, mas também internamente" (KOSELLECK, 1999, p. 29).

A problemática da teoria do Estado de Hobbes consistia em estabelecer limites externos às distintas ações provenientes de uma pluralidade de crenças. Hobbes queria instituir um poder comum suficientemente forte, capaz de impedir o conflito das convicções de cada um, da discórdia das vontades sem limites. Para tanto, distinguia o Direito da Moral e, como se viu, somente as ações externas pertencem ao mundo jurídico e são passíveis de punição. Todavia, em meio ao conflito religioso que marcava seu tempo, ocasionado pela constelação de razões ou consciências privadas, cada homem atuava como um juiz em causa própria e não havia um poder comum, mas uso da força privada ditado pelo direito natural de autopreservação. Na Filosofia Política do autor, quando não há uma consciência pública representada pela vontade soberana do Estado, predomina o "tribunal da lei natural", que nada mais é do que a consciência de cada um (HOBBES, 1983, p. 210). Na batalha que se travava entre as razões ou consciências privadas, cada homem queria expor suas verdades religiosas fundamentando-as como fatos milagrosos. Assim, disputavam a veracidade de suas crenças religiosas que se confundiam com suas leis naturais ou morais. Hobbes, no ímpeto de reconfigurar o mundo moral e fundar o Estado, procura despir as consciências privadas de repercussão política. $\mathrm{Na}$ sua teoria do Estado, as crenças, a moral, as verdades de cada homem, isto é, suas consciências, não têm nenhuma aplicação na realização das leis, pois elas são feitas, exclusivamente, "pela vontade daquele ou daqueles que têm o soberano poder" (idem, p. 217). A consciência de cada um está sujeita à consciência do soberano, que, por meio da manifestação da sua vontade, torna-a pública, isto é, sua vontade é a lei. As decisões políticas não pertencem mais ao juízo particular proveniente da consciência de cada um; agora quem tem o direito de decidir é soberano. Os valores morais, as crenças e as verdades de cada um devem ser relegados a um plano secreto, a consciência deve ser escamoteada, uma vez que no âmbito político e jurídico, isto é, no âmbito das ações externas, não são as verdades provenientes de crenças que fazem a lei, mas sim a autoridade. Assim, Hobbes solucionou o problema da seguinte forma: auctoritas, non veritas facit legem. Se a crença em milagres, nas Escrituras Sagradas ou nas leis morais da consciência são verdade ou mentira, trata-se de um problema de foro íntimo. Porém, se for de foro externo, isto é, da esfera pública, "nenhum de nós deve aceitar como juiz sua razão ou consciência privada, mas a razão pública, isto é, a razão do supremo lugar-tenente de Deus. E, sem dúvida, já o escolhemos como juiz, se já lhe demos um poder para fazer tudo quanto o necessário para nossa paz e defesa" (idem, p. 264). Hobbes, ao declarar que nenhum homem deve aceitar como juiz sua consciência privada, isto é, aceitar sua razão particular como medida do bem e do mau no que respeita a suas ações externas, está submetendo as consciências privadas à consciência pública, que é a vontade política do soberano vestida com força de lei. Em outras palavras, o conteúdo moral das decisões de cada homem que repercutem nas suas ações externas é transferido à vontade soberana do Estado, isto é, às leis, que garantem liberdades negativas. Portanto, deve-se atentar como até hoje a teoria do Estado de Hobbes repercute no Direito moderno dos denominados estados democráticos do mundo ocidental.

Aqui se deve fazer uma breve digressão. Habermas, ao tecer reflexões sobre o Direito moderno dos referidos estados, argumenta que "o Direito moderno tira dos indivíduos o fardo das normas morais e transfere-as para as leis que garantem as compatibilidades das liberdades de ação. Essas obtêm sua legitimidade através de um processo legislativo que, por sua vez, apóia-se no princípio da soberania do povo" (HABERMAS, 1997, p. 114). Veja-se que os vivos princípios da 
doutrina do Estado de poder absolutista de Hobbes preocupam Habermas, uma vez que encontram eco, ainda hoje, no processo legislativo democrático, que tira dos indivíduos os motivos que os levam a orientar suas ações em sociedades complexas. No intuito de reestruturar as engrenagens do sistema de direitos, salienta Habermas que "o processo legislativo democrático precisa confrontar seus participantes com as expectativas normativas das orientações do bem da comunidade, porque ele próprio extrai sua força legitimadora do processo de um entendimento dos cidadãos sobre regras de sua convivência" (idem, p. 14). O esforço de Habermas para alcançar o seu ideal de uma democracia radical, que transforme destinatários de direitos em autores de leis com a capacidade de definir, por meio de mútuo entendimento, seus critérios do que é justo ou injusto, representa uma utopia que se esquece do caráter "estatal do Estado" (KOSELLECK, 1999, p. 35). A construção da teoria do Estado de Hobbes tem como finalidade impedir que indivíduos invoquem sua consciência, isto é, seus critérios de justiça ou injustiça, uma vez que são relativos e, ao exteriorizarem-se, levam à discórdia e terminam em guerra, que é a volta ao estado de natureza. A razão de Estado de Hobbes surge justamente para limitar as razões privadas, que, sem amparo externo, descambam para violência das ações.

Hobbes, que viveu a torpeza da guerra religiosa, jamais concordaria com Habermas quanto ao projeto político de modificar "o sistema jurídico [que] tira das pessoas jurídicas, em sua função de destinatárias, o poder de definição dos critérios de julgamento do que é justo e do que é injusto" (HABERMAS, 1997, p. 151). Todavia, deve-se salientar que ambos os autores viveram e vivem em momentos históricos inteiramente distintos. Se Habermas sente-se inquieto e ávido por propor o seu projeto político de democracia radical, deve-o à teoria política de Hobbes, pois este contribuiu para a secularização da política ao elaborar seu conceito de Estado absolutista, cujo maior benefício foi a idéia de neutralizar os violentos conflitos religiosos e garantir a paz e a ordem no interior de um corpo político. O próprio Habermas parece reconhecer tal contribuição, já que sua "inquietação possui uma razão mais profunda: ela deriva do pressentimento de que, numa época de política inteiramente secularizada, não se pode manter um Estado de direito sem democracia radical" (idem, p. 13). Invertendo os dizeres de Habermas, é possível dizer que sem uma época de política inteiramente secularizada não há Estado de direito e, portanto, jamais se poderia pensar em democracia radical.

Voltando à teoria constitucional do Estado de Hobbes, cumpre esclarecer que o autor reconhece a liberdade de pensamento em foro íntimo, pois é cônscio de que "os pensamentos secretos de cada homem percorrem todas as coisas, sagradas ou profanas, limpas ou obscenas, sérias ou frívolas, sem vergonha ou censura" (HOBBES, 1983, p. 44). Todo problema consiste em quando os homens cuja tendência à credulidade no ininteligível evidenciada por Hobbes - desejam invocar, exteriorizar, as fantasias de seu foro íntimo, pois "em épocas de desgraça tendem a invocá-las, e quando esperam um bom sucesso tendem a agradecer-lhes, transformando em seus deuses as criaturas de sua própria fantasia" (idem, p. 64).

A reviravolta do caos da guerra civil-religiosa conduziu as reflexões políticas de Hobbes à distinção entre fé e confissão pública. Tal distinção abriu a perspectiva para o autor também delinear as diferenças entre política e religião, Moral e Direito; enfim, o autor, ao forjar seu conceito de razão de Estado, isto é, ao submeter as consciências privadas à consciência pública, a lei que orienta a ação no interior de um Estado (idem, p. 193), não deixou de reconhecer a liberdade de pensamento no âmbito do foro íntimo. Como dizia, "um particular tem sempre a liberdade (visto que o pensamento é livre), de acreditar ou não acreditar, em seu foro íntimo, nos fatos que lhe forem apresentados como milagres, conforme veja qual o benefício que sua crença pode acarretar para os fins que afirmam ou negam e conjecturando daí se eles são milagres ou mentiras. Mas quando se trata da profissão pública dessa fé a razão privada deve submeter-se à razão pública, quer dizer, ao lugar-tenente de Deus" (idem, p. 264).

O epítome da passagem acima é retratado pela já comentada expressão auctoritas, non veritas facit legem. É necessário esmiuçar os desdobramentos da referida máxima, pois estendem-se às relações entre política, religião, Moral e Direito e, por fim, culminam nas primícias do Positivismo Jurídico. Aliás, parece-me que, na luta para secularizar o Estado, isto é, no esforço para emancipar um domínio político incólume, independente dos modelos tradicionais de fé e autoridade ou até mesmo das correntes do pensamento jusnaturalista de 
seu tempo, Hobbes destitui leis naturais ou divinas, leis fundadas na experiência e observação de precedentes (isto é, a jurisprudência) de qualquer significado e, sobretudo, de repercussão política. As verdades que derivam do conhecimento prudencial alcançado com muito estudo e observação, as revelações das vontades de Deus, as leis naturais aparentemente eternas e universais, não têm validade quando se arrogam pretensões políticas, ou seja, quando pretendem validade na esfera pública, cuja característica é reger-se pelo interesse da autoridade estatal.

Embora o autor utilize-se de leis naturais na construção de sua teoria do Estado e, aparentemente, concorde com os filósofos morais de seu tempo quanto ao caráter eterno e universal das leis de natureza, Hobbes as esvazia de conteúdo. Aproximando-se dos filósofos morais, o autor chega a explicar que a ciência das leis naturais "é a verdadeira filosofia moral. Porque a filosofia moral não é mais do que a ciência do que é bom e do mau, na conservação da sociedade humana". Todavia, logo em seguida, o autor nega que possam ser eternas e universais, pois "o bem e o mal são nomes que significam nossos apetites e aversões, os quais são diferentes conforme os diferentes temperamentos, costumes e doutrinas dos homens. E os homens diversos não divergem, apenas, em seu julgamento [...]; divergem também quanto ao que é conforme ou desagradável à razão, nas ações da vida cotidiana. Mas, o mesmo homem, em momento diferentes, diverge de si mesmo, às vezes louvando, isto é, chamando bom àquilo mesmo que outras vezes despreza e a que chama mau. Daqui procedem desculpas, controvérsias e finalmente a guerra" (idem, p. 94).

A citação acima revela que não há leis naturais, divinas ou morais capazes de orientar a conduta humana. $\mathrm{O}$ quadro de miséria cognitiva inerente à antropologia elaborada por Hobbes impede qualquer espécie de conhecimento seguro. Por isso, para o autor, "as lei, escritas ou não, recebem toda sua força e autoridade da vontade do Estado, quer dizer, da vontade do representante" (idem, p. 163). Não importa se a vontade soberana do Estado é justa ou injusta, verdadeira ou falsa; o monarca de Hobbes "está acima do direito e é sua fonte; ele decide o que é justo ou injusto; é, ao mesmo tempo, legislador e juiz" (KOSELLECK, 1999, p. 31). Como diz o próprio Hobbes, "o soberano não está sujeito àquelas leis que ele próprio, ou melhor, que o Estado fez. Pois estar sujeito a leis é estar sujeito ao Estado, isto é, ao soberano representante, isto é, a si próprio, o que não é sujeição, mas liberdade em relação às leis" (HOBBES, 1983, p. 194).

Ao argumentar que as leis tiram sua força e autoridade da vontade soberana do Estado, Hobbes está igualando autoridade e poder, isto é, auctoritas e potestas, poder espiritual (invisível) e poder temporal (visível). Mas Hobbes também se opõe a outras doutrinas - não só às doutrinas de católicos e daquela "Igreja que mais presumiu de Reforma" (idem, p. 73) - que ameaçavam o poder absoluto do Estado. Refutava "aquelas opiniões que se encontram no livro de eminentes juristas de vários Estados, segundo as quais o poder legislativo depende diretamente ou por conseqüência de indivíduos particulares ou juízes particulares" (idem, p. 163). Ao negar as referidas opiniões o autor entra em polêmica com as idéias do eminente jurista Sir Edward Coke. Aqui Hobbes sustenta a primazia do Direito Positivo ou statute law, isto é, do Direito posto pela vontade soberana, em relação ao Direito comum, "que surge diretamente das relações sociais e é acolhido por juízes nomeados pelo Rei; numa segunda fase, ele se torna direito de elaboração judiciária" (BOBBIO, 1995, p. 32). Como se viu, Hobbes rejeita a elaboração de leis provenientes de qualquer razão privada, seja de representantes espirituais, mercadores, juízes - enfim, ninguém, senão a autoridade suprema do Estado, tem o poder de pôr normas, que somente são jurídicas em face do monopólio da força física, isto é, do poder coercitivo. Além do mais, o autor não crê que se possa extrair conseqüências de fatos passados para aplicação de casos presentes ou futuros, ou seja, o conhecimento tirado da experiência de fatos passados para solução de casos presentes é falível, ainda que se disponha de muita memória, estudo e observação. Se Hobbes já era cético com relação às conseqüências extraídas da ciência, no que respeita ao conhecimento prudencial era mais ainda. Para o autor, "os sinais da ciência são uns certos e infalíveis, outros incertos". Já "os sinais da prudência são todos incertos, porque observar pela experiência e lembrar todas as circunstâncias que podem alterar o sucesso é impossível" (HOBBES, 1983, p. 31).

Assim, das razões expostas é corolário dizer que as leis não provêm "de nenhuma razão privada, 
porque nesse haveria tantas contradições nas leis como há nas Escolas. Nem tampouco (como pretende Sir Edward Coke) de uma perfeição artificial da razão, obtida através de muita observação e experiência (como era a dele)" (idem, p. 164). Antes de prosseguir, deve-se salientar que a referida passagem é retirada do capítulo XXVI do Leviatã, dedicado às leis civis. Embora somente na referida passagem faça breve menção ao juiz Sir Edward Coke, Hobbes retoma a discussão com o jurista no livro A Dialogue between a Philosopher and a Student of the Common Laws of England, publicado em 1681, dois anos após a morte do autor. O referido capítulo do Leviatã consiste em uma síntese de uma discussão que se estende e aprofunda no outro livro. Estruturado em forma de diálogo, o mencionado livro retrata uma disputa entre o filósofo - que é o próprio Hobbes - e um estudante do Direito comum, criado pelo autor, para representar o papel de um discípulo das idéias de Sir Edward Coke.

No Leviatã, Hobbes responde à teoria de Coke argumentando que não é a perfeição da razão artificial, obtida por meio do conhecimento fundado na experiência que faz a lei, mas sim o "poder fático de mando de um soberano, cuja vontade pode dominar qualquer outra vontade sobre a terra" (HABERMAS, 1997, p. 175). Hobbes compreende que não é o conhecimento de espécie alguma que faz a lei, mas sim a autoridade de quem tem o poder coercitivo, isto é, aquele representante do Estado que tem o poder de fazer a guerra e estabelecer a paz. Na teoria do Estado absoluto do autor, a jurisprudência não é fonte de lei, "portanto, o que faz a lei não é aquela juris prudentia, ou sabedoria dos juízes subordinados, mas a razão deste nosso homem artificial, o Estado, em seu representante, uma só pessoa, não é fácil surgir qualquer contradição nas leis, e quando tal acontece a mesma razão é capaz, por interpretação ou alteração, de eliminar a contradição. Em todos os tribunais de justiça quem julga é o soberano (que é a pessoa do Estado). O Juiz subordinado deve levar em conta a razão que levou o soberano a fazer determinada lei, para que sua sentença seja conforme a esta, e nesse caso a sentença é uma sentença do soberano, caso contrário é dele mesmo, e é injusta" (HOBBES, 1983, p. 164). De imediato é necessário salientar que Hobbes esvazia a noção de justiça de qualquer conteúdo, pois justiça é sentenciar de acordo com a vontade do soberano. Sua concepção de justiça tem mero caráter formal, pois não importa qual é o conteúdo da decisão da autoridade representativa do Estado, ela está desconectada de qualquer princípio moral ou religioso. A decisão é justa na medida em que sua fonte for a vontade soberana da pessoa representativa do Estado, pois a "decisão política do príncipe tem força de lei” (KOSELLECK, 1999, p. 31). Para Hobbes, a legalidade ou validade das leis não reside em seu conteúdo religioso ou político, mas na sua função de garantir a ordem e tranqüilidade no interior de um Estado. O conceito de legalidade das leis, isto é, de lei formal, proveniente da vontade soberana do Estado, descortina as primícias do positivismo jurídico. Aliás, creio, as idéias do autor aproximam-se muito mais do positivismo jurídico do que do jusnaturalismo. Embora Bobbio corretamente reconheça que a principal finalidade da doutrina política de Hobbes é lutar contra o poder eclesiástico, "aquilo que Hobbes diz para justificar sua posição contra o direito comum é muito importante, tanto que pode ser considerado o precursor do positivismo jurídico" (BOBBIO, 1995, p. 34).

A passagem em que Hobbes professa que a lei não é feita pela jurisprudência ou sabedoria dos juízes subordinados, mas pela razão do homem artificial, representada pelo soberano, equivale a mais um dos desdobramentos da máxima auctoritas, non veritas facit legem. No livro $A$ Dialogue between a Philosopher and a Student of the Common Laws of England, os mesmos dizeres aparecem para contestar as teorias de um personagem que seria o discípulo de Edward Coke. Portanto, Hobbes salienta que "It is not wisdom, but Authority that makes the law" (HOBBES, 1971, p. 55): a lei não deriva sua validade do conhecimento ou sapiência de quem quer que seja; ela deriva de quem tem o poder legislativo. Assim, "o fundamento do Direito deixou de ser buscado nos ditames da razão e passou a afirmar-se na vontade do legislador, independentemente de qualquer juízo sobre a conformidade desta vontade com a razão. Nesse sentido o processo de laicização e sistematização do Direito terminou por confluir com o fenômeno da crescente positivação do Direito pelo Estado, que é outro processo característico da experiência jurídica no mundo moderno" (LAFER, 1988, p. 39). 


\section{CONCLUSÃO}

A resposta de Hobbes à guerra civil religiosa foi a secularização de um domínio estritamente político, independente de juízos morais, leis naturais ou interesses de representantes dos poderes espirituais. Todavia, não se deve perder de vista que este domínio secular é extraído da interpretação das Escrituras Sagradas. É justamente a exegese e hermenêutica do Novo e do Velho Testamento que permite o uso e a transferência de princípios teológicos para formação de conceitos seculares da teoria política - precisamente, para a teoria do Estado. Não é por acaso que o autor chama o soberano intramundano de "Deus mortal" ou que afirma que a "soberania é a alma artificial" do Estado. São inúmeras as passagens do Leviatã em que se torna inequívoca a analogia que há entre a estrutura semântica de conceitos teológicos e conceitos políticos ou jurídicos, como ocorre, a título de exemplo, entre as noções de crime e pecado, foro externo e foro interno, confissão e fé, Direito e Moral, código jurídico e Bíblia. O conceito político de soberania absoluta de Hobbes é um conceito teológico secularizado, revelando verdadeira translação conceitual do espiritual para o temporal. Demonstrando que o significado do conceito de secularização no Leviatã pode ser pensado como a conversão de um Deus todopoderoso na figura de um soberano intramundano onipotente cujas mãos detêm o bastão espiritual do controle da manifestação externa das crenças e o poder coercitivo da espada. Hobbes não deixa de restaurar um princípio pagão no qual os gentios não separavam a religião da política, pois a união dos poderes invisíveis aos poderes visíveis garantia a estabilidade e previsibilidade dos governos de domínios temporais.

A construção de um Estado neutro, acima de qualquer partido político ou seitas religiosas, levou ao positivismo jurídico. No seu conceito de lei formal não importa o conteúdo, isto é, o valor da lei. Exige que a lei seja proveniente de autoridade competente dotada de poder coercitivo. O Direito, assim como a religião, não passa de um instrumento a serviço de quem tem o poder fático de mando. A teoria política de Hobbes, provavelmente, é incômoda, pois alerta para o caráter arbitrário do poder de mando que homens exercem sobre homens. Aliás, o traço arbitrário e realista do poder não guarda nenhuma relação com as leis naturais ou morais, como o conhecimento tirado das verdades de Deus, dos ditames da razão e da sapiência de juízes. Ao secularizar o Estado, Hobbes descortina o caráter arbitrário das relações de poder que os homens travam entre si, sejam eles papas, príncipes ou aiatolás. Assim, ao distinguir consciência interior da ação exterior, Moral de Direito, procura eliminar os conflitos violentos que ocorriam no interior de um Estado, sem poder comum suficientemente forte para manter a paz. Ao transformar o Leviatã em arma política voltada para a secularização do Estado, Hobbes busca a salvação dos homens neste mundo no interior de um corpo político. Assim, o Estado passa a representar uma "mútua relação de proteção e obediência" (HOBBES, 1983, p. 410) necessária à condição existencial da natureza humana. Se fora do Estado "o homem é lobo do homem", no seu interior adquire status de cidadão e "o homem é um deus para o homem" (HOBBES, 1998, p. 3).

Pedro Hermílio Villas Bôas Castelo Branco (pvillasboas@iuperj.br) é Doutorando em Ciência Política no Instituto Universitário de Pesquisa do Rio de Janeiro (IUPERJ).

\section{REFERÊNCIAS BIBLIOGRÁFICAS}

ARENDT, H. 1972. Entre o passado e o futuro. São Paulo : Perspectiva. 1987. A condição humana. $3^{\text {a }}$ ed. Rio de Janeiro : Forense-Universitária. 1988. Da revolução. Brasília : UNB.

CASTELO BRANCO, P. H. V. B. 2000. Razão e história. Após, Rio de Janeiro, n. 2, p. 179-192.
BÍBLIA. Português. 1982. Bíblia sagrada. Trad. Centro Bíblico Católico. $34^{\mathrm{a}}$ ed. São Paulo : Claretiana.

BOBBIO, N. 1991. Thomas Hobbes. $5^{\text {a }}$ ed. Rio de Janeiro : Campus. 1995. O Positivismo Jurídico. São Paulo : Ícone. 
HABERMAS, J. 1997. Direito e democracia : entre facticidade e validade. Rio de Janeiro : Tempo Brasileiro.

HOBBES, T. 1946. Leviathan or The Matter, Forme and Power of a Common Wealth Ecclesiatical and Civil. London: Mowbray.

. 1971. A Dialogue Between a Philosopher and a Student of The Common Laws of England. Chicago : University of Chicago.

1983. Leviatã ou matéria, forma e poder de um Estado eclesiástico e civil. $3^{\mathrm{a}}$ ed. São Paulo : Abril Cultural.

1985. Leviathan. London : Penguin.

1990. Behemoth; or the Long Parliament. Chicago : University of Chicago.

1998. Do cidadão. $2^{\mathrm{a}}$ ed. São Paulo : M. Fontes.

HUME, D. s/d. Uma investigação sobre os princípios da moral. Campinas : UNICAMP.

KOSELLECK, R. 1985. Future Past. On the Semantics of Historical Time. Cambridge, Mass. : Massachusetts Institute of Technology.

1999. Crítica e crise : uma contribuição à patogênese do mundo burguês. Rio de Janeiro : Contraponto.

LAFER, C. 1988. A reconstrução dos direitos humanos : um diálogo com o pensamento de Hannah Arendt. São Paulo : Cia. das Letras.

MACPHERSON, C. B. 1985. Introduction. In : HOBBES, T. Leviathan. London : Penguin.

MAQUIAVEL, N. 1950. Discurso sobre a primeira década de Tito Lívio. In : Pensadores italianos. V. XXVI. Rio de Janeiro : W. M. Jackson.

MARRAMAO, G. 1997. Céu e Terra : genealogia da secularização. São Paulo : UNESP.

PIERUCCI, A. F. 1998. Secularização em Max Weber : da contemporânea serventia de voltarmos a acessar aquele velho sentido. Revista Brasileira de Ciências Sociais, São Paulo, v. 13, n. 37, p. 43-73, jun.

2003. O desencantamento do mundo : todos os passos do conceito em Max Weber. São Paulo : ed. 34.

REALE, M. 1965. Filosofia do Direito. São Paulo : Saraiva.

1979. Lições preliminares de Direito. $19^{\mathrm{a}}$ ed. São Paulo : Saraiva.

2000. Filosofia do Direito. $19^{\mathrm{a}}$ ed. São Paulo : Saraiva.

RIBEIRO, R. J. 1991. Hobbes : o medo e a esperança. In : WEFFORT, F. (org.). $O s$ clássicos da política. V. I. São Paulo : Ática.

1998. Apresentação. In : HOBBES, T. Do cidadão. São Paulo : M. Fontes.

1999. Ao leitor sem medo: Hobbes escrevendo contra seu tempo. $2^{\mathrm{a}}$ ed. Belo Horizonte : UFMG.

ROMANO, R. 1997. Apresentação. In : MARRAMAO, G. Céu e Terra : genealogia da secularização. São Paulo : UNESP.

SCHMITT, C. 1988. Political Theology : Four Chapters on the Concept of Sovereignty. Cambridge, Mass. : Massachusetts Institute of Technology.

1992. O conceito do político. Petrópolis : Vozes.

1996. The Leviathan in the State Theory of Thomas Hobbes : Meaning and Failure of a Political Symbol. London : Greenwood.

STRAUSS, L. 1979. O Estado e a Igreja. In : QUIRINO, C. \& SOUZA, M. (orgs). $O$ pensamento político clássico. São Paulo : T. A. Queiróz.

. 1984. The Political Philosophy of Hobbes. Its Basis, Its Genesis. Chicago : University of Chicago. 